\title{
Analisis Hukum Pertanggungjawaban Pidana Korporasi dalam Tindak Pidana Pencucian Uang (Money Laundering)
}

\author{
Legal Analysis of Corporate Criminal Liability in Money \\ Laundering
}

\author{
La Ode Abdul Razak \\ Universitas Halu Oleo \\ E-mail: Laodeabdulrazak88@gmail.com \\ Oheo K. Haris \\ Pascasarjana Universitas Halu Oleo \\ E-mail: oheokh@gmail.com \\ Sabrina Hidayat \\ Pascasarjana Universitas Halu Oleo \\ E-mail: sabrina.hidayat54@yahoo.com
}

\begin{abstract}
This research aims to determine the forms of corporate responsibility for committing money laundering and to find out the mechanisms for handling corporate cases that commit money laundering. This research is normative, so the data collection method used is secondary data, that is data obtained or collected by researchers from existing sources. The results of the research show that 1) Criminal liability towards corporations regulating the expansion of the conviction of money laundering criminals, so that legal subjects can be convicted, because if it is only based on legal subjects, then only criminal subjects can be subject to criminal matters in the sense of this matter. human. But the subject of Corporate Law can also be convicted. And where the types of principal criminal sanctions that can be imposed on corporate legal subjects for money laundering are criminal fines with a maximum amount of $\mathrm{Rp}$. 100,000,000,000.00 (one hundred billion rupiah) and additional penalties in the form of (a) announcement of a judge's decision, (b) Suspension of part or all of the corporation's business activities, (c) revocation of business licenses, (d) dissolution and/or prohibition of corporations, (e) confiscation of corporate assets for the state, and/or (f) takeovers of corporations by the state. 2) The mechanism for the handling of corporate cases in this case refers to the Supreme Court Regulation No. 13 of 2016 as a source of procedural law so that there is no legal vacuum for corporate perpetrators who commit criminal acts, in the mechanism of handling corporate cases where the Supreme Court Regulations are intended as a guideline for law enforcement agencies in handling criminal cases within the scope of corporate crime.
\end{abstract}


Keywords: Corporate Criminal Liability; Corporate management; Money Laundering

\begin{abstract}
Abstrak: Penelitian ini bertujuan untuk mengetahui bentuk pertanggungjawaban korporasi yang melakukan tindak pidana pencucian uang dan untuk mengetahui mekanisme tata cara penanganan perkara korporasi yang melakukan tindak pidana pencucian uang. Penelitian ini bersifat normatif maka metode pengumpulan data yang digunakan adalah data sekunder yaitu data yang diperoleh atau dikumpulkan oleh peneliti dari sumber-sumber yang telah ada. Hasil penelitian menunjukkan bahwa 1) Pertanggungjawaban pidana terhadap korporasi yang mengatur tentang perluasan dapat dipidananya pelaku tindak pidana pencucian uang, sehingga dapat dipidananya subjek hukum, karena apabila hanya mendasarkan pada subjek hukum, maka yang dapat dijatuhi pidana hanyalah subjek hukum orang dalam pengertian hal ini dimaksud manusia. Namun subjek Hukum Korporasi juga dapat dipidana. Dan dimana jenis sanksi pidana pokok yang dapat dijatuhkan terhadap subjek hukum korporasi untuk tindak pidana pencucian uang adalah pidana denda dengan jumlah maksimum Rp.100.000.000.000,00 (seratus miliar rupiah) dan pidana tambahan berupa (a) pengumuman putusan hakim, (b) Pembekuan sebagian atau seluruh kegiatan usaha korporasi,(c) pencabutan izin usaha,(d) pembubaran dan/atau pelarangan korporasi,(e) perampasan aset korporasi untuk negara, dan/atau (f) pengambilalihan korporasi oleh negara. 2) Mekanisme tata cara penanganan perkara korporasi dalam hal ini merujuk pada Peraturan Mahkamah Agung Nomor 13 Tahun 2016 sebagai sumber hukum acara agar tidak terjadi kekosongan hukum bagi pelaku korporasi yang melakukan tindak pidana, dalam mekanisme penanganan perkara korporasi dimana Peraturan Mahkamah Agung ini bertujuan sebagai pedoman bagi penegak hukum dalam penanganan perkara pidana dalam ruang lingkup kejahatan korporasi.
\end{abstract}

Kata kunci: Pertanggungjawaban Pidana Korporasi; Pengurus Korporasi; Pencucian Uang

\title{
PENDAHULUAN
}

Kehidupan ekonomi antara satu negara dengan negara lain semakin tergantung, sehingga ketentuan hukum di bidang perdagangan internasional dan bisnis transnasional semakin diperlukan dahulu ada semacam adagium yang menyatakan makin miskin suatu bangsa semakin tinggi tingkat kejahatan yang terjadi. Sekarang adagium ini hanya berlaku bagi kejahatan konvensional seperti perampokan, pencurian, penipuan, penggelapan, dan lainlain.

Tindak pidana pencucian uang dapat dilakukan dalam berbagai bentuk, tidak hanya melalui sistem keuangan, investasi langsung, tetapi juga disembunyikan dalam bentuk harta benda seperti properti, kendaraan, perhiasan dan lain sebagainya. Untuk itulah kemudian pandangan atas penegakan hukum sedikit demi sedikit berubah, diawali 
dengan penegakan hukum atas tindak pidana yang dilakukan oleh pelaku tindak pidana, dimana pelaku akan menjadi objek bagi penegakan hukum yang dilakukan.

Saat ini penegakan hukum dilakukan pula dengan melakukan kriminalisasi atas penggunaan ataupun pemanfaatan dana atau harta kekayaan yang diperoleh dari hasil tindak pidana. Pada dasarnya, tidak ada di antara kita semua yang berkenan melihat seseorang menikmati kehidupan dengan memperoleh dana atau harta kekayaan secara ilegal. Oleh karena itu, baik tindak pidana yang dilakukan sebagai pidana asalnya maupun tindakan memanfaatkan dana berasal dari hasil tindak pidana tersebut sudah seharusnya dapat dikenakan pemidanaan yang berbeda.

\section{METODE PENELITIAN}

Tipe penelitian yang penulis gunakan dalam penelitian adalah penelitian normatif. Adapun pendekatan yang penulis gunakan dalam penelitian ini adalah pendekatan perundang-undangan (statute approach), pendekatan kasus (case approach) dan pendekatan konsep. Teknik pengumpulan bahan hukum yang mendukung dan berkaitan dengan pemaparan penelitian ini adalah studi dokumen (studi kepustakaan), yang dilakukan dengan cara meneliti bahan-bahan pustaka atau data sekunder yang terdiri dari bahan hukum primer, bahan hukum sekunder dan bahan hukum tertier.

\section{ANALISIS DAN PEMBAHASAN}

\section{Asas Kesalahan Sebagai Salah Satu Unsur Yang Harus Dipenuhi Subjek Hukum Untuk Dapat Dipidana}

Pertanggungjawaban mutlak atau bisa diartikan sebagai istilah tanggung jawab seketika atau langsung, hal ini sangat berbanding terbalik dengan sistem atau usur-unsur tanggung jawab pidana yang sifatnya kumulatif dengan salah satu unsurnya adalah harus adanya suatu bentuk kesalahan yang berupa kesengajaan atau kealpaan sebagai mana yang sudah dijelaskan sebelumnya mengenai pertanggung jawaban pidana, dengan merujuk asas yang di dalam pertanggung jawaban pidana yaitu tiada pidana jika tidak ada kesalahan (geen straf zonder schuld; actus non facit reum nisi mens sir rea (tentunya juga pada hakikatnya dalam penjelasan mengenai pertanggungjawaban pidana unsur kesalahan ini adalah merupakan hal yang sangat penting dalam menentukan seseorang telah melakukan tidak pidana atau tidak. ${ }^{1}$

1 Alfitra, Modus Operandi Pidana Khusus di Luar KUHP, Jakarta: Penerbit Raih Asa Sukses, 2014, hlm. 36. 
Pertanggungjawaban mutlak atau bisa dikatakan tanggung jawab seketika atau langsung dalam hukum pidana, dimana hal ini dapat dikaitkan dengan konsep asas strict liability yang definisi dari asas tersebut adalah pertanggungjawaban pidana tanpa kesalahan dimana pembuat sudah dapat dipidana apabila ia telah melakukan perbuatan pidana sebagaimana dirumuskan undang-undang, tanpa melihat sikap batinnya.

Kesalahan merupakan salah satu unsur yang fundamental di samping sifat melawan hukum dari perbuatan, dan harus dipenuhi agar suatu subjek hukum dapat dijatuhi pidana. Menurut Sudarto, dipidananya seseorang tidaklah cukup apabila orang itu telah melakukan perbuatan yang bertentangan dengan hukum atau bersifat melawan hukum. Jadi meskipun pembuatnya memenuhi rumusan delik dalam undang- undang dan tidak dibenarkan (an objective breach of a penal provision) ${ }^{2}$, namun hal tersebut belum memenuhi syarat untuk menjatuhkan pidana. Untuk pemidanaan masih perlu adanya syarat, bahwa orang yang melakukan perbuatan itu mempunyai kesalahan atau bersalah (subjective guild). Dengan perkataan lain, orang tersebut harus dapat dipertanggungjawabkan atas perbuatannya atau jika dilihat dari sudut perbuatannya baru dapat dipertanggungjawabkan kepada orang tersebut. Di sini berlaku apa yang disebut "asas tiada pidana tanpa kesalahan" (keine strafe ohne schuld atau geen straf zonder schuld atau nulla poena sine culpa), culpa di sini dalam arti luas meliputi juga kesengajaan. ${ }^{3}$

Kesalahan/schuld merupakan dasar dalam pertanggungjawaban pidana. Kesalahan merupakan keadaan jiwa dari si pembuat dan hubungan batin antara si pembuat dan perbuatannya. Adanya kesalahan pada seseorang, maka orang tersebut dapat dicela. Mengenai keadaan jiwa dari seseorang yang melakukan perbuatan merupakan apa yang lazim disebut sebagai kemampuan bertanggungjawab, sedangkan hubungan batin antara si pembuat dan perbuatannya itu merupakan kesengajaan, kealpaan, serta alasan pemaaf. Dengan demikian, untuk menentukan adanya kesalahan subjek hukum harus memenuhi beberapa unsur, antara lain:4

2 Remy Syahdeini Sutan, Seluk Beluk Tindak Pidana Pencucian Uang dan Pembiayaan Terorisme, Jakarta: Pusat Pustaka Grafiti, 2007, hlm. 90.

3 Roland Robertson, “Globalization, Social Theory and Global Culture”, dalam Khudzaifah Dimyati \& Kelik Wardiono (ed), Problema Globalisasi: Perspektif Sosiologi Hukum, ekonomi dan Agama, Surakarta: Muhammadiyah University Press, 2001, hlm. 86.

4 Chazawi Adami, Pelajaran Hukum Pidana Bagian Penafsiran Hukum Pidana Dasar Peniadaan Pemberatan \& Peringanan Kejahatan Aduan, Perbarengan \& Ajaran Kausalitas, Jakarta: PT Raja Grafindo Persada, 2002, hlm. 76. 
a. Adanya kemampuan bertanggung jawab pada si pembuat,

b. Hubungan batin antara si pembuat dan perbuatannya yang berupa kesengajaan (dolus) atau kealpaan (culpa),

c. Tidak adanya alasan penghapus kesalahan atau tidak adanya alasan pemaaf

Ketiga unsur ini merupakan satu kesatuan yang tidak dapat dipisahkan antara satu dengan yang lain, dimana unsur yang satu bergantung pada unsur yang lain. Dalam perkembangan zaman tentunya ada perubahan tentang perkembangan pemahaman tindak pidana saat ini yang lahir dari beberapa penelitian yang dilakukan para ahli pidana. Yaitu salah satunya penerapan asas strict liability dalam tindak pidana tertentu, yang sering diartikan secara singkat sebagai liability without fault (pertanggungjawaban tanpa kesalahan).$^{5}$

\section{Kedudukan Asas “Geen Straf Zonder Schuld” dalam Pertanggungjawaban Pidana Korporasi}

Asas "tiada pidana tanpa kesalahan" merupakan asas yang fundamental dalam hukum pidana. Bahkan sedemikian fundamentalnya, asas ini telah meresap dan menggema dalam hampir semua ajaran dalam hukum pidana. Asas ini juga terdapat dalam hukum pidana Belanda yang dikenal dengan istilah "geen straf zonder schuld" dan di Jerman yang dikenal dengan istilah "keine straf ohne schuld". Dalam hukum pidana di Inggris juga terdapat asas yang serupa yang dalam bahasa Latin berbunyi: "actus non facit reum nisi mens sit rea" atau diterjemahkan ke dalam bahasa Inggris sebagai an act does not make a person guilty until the mind is guilty. ${ }^{6}$

Asas kesalahan merupakan asas yang mutlak ada dalam hukum pidana, yaitu sebagai dasar untuk menjatuhkan pidana. Akan tetapi, bagaimana kedudukan asas ini dalam memidana korporasi. Korporasi meskipun diposisikan sebagai subjek tindak pidana tapi tidak bisa disamakan dengan manusia.

Korporasi pada dasarnya tidak termasuk kategori manusia sehingga korporasi tidak memiliki hak layaknya manusia, tidak dapat melaksanakan semua kewajiban, dan tidak dapat melakukan tindakan hukum layaknya manusia. Korporasi juga tidak memiliki

$5 \quad$ Welling N Sarah, "Smurf. Money laundering and the United States Criminal Federal Law", dalam Brent Fisse, David Fraser \& Graeme Coss, Economics and Ideology on the Money Trail (Confiscation of Proceeds of Crime, Money Laundering and Cash Transaction Reporting), Sydney: The Law Book Company Limited, 1992, hlm. 34.

6 Muladi dan Barda Nawawi Arief, Teori-teori dan Kebijakan Hukum Pidana, Bandung: Alumni, 2005, hlm. 76. 
jiwa layaknya manusia sehingga tidak memenuhi unsur-unsur psikis untuk dapat dikatakan memiliki kesalahan.

Jika melihat ke dalam ketentuan dari KUHP, maka asas ini tidak akan ditemukan secara tertulis sebagaimana asas legalitas pada Pasal 1 ayat (1) KUHP. Menurut Moeljatno, asas "tiada pidana tanpa kesalahan" merupakan asas tidak tertulis dalam hukum yang hidup dalam anggapan masyarakat dan tidak kurang keberlakuannya daripada asas yang tertulis, seperti asas legalitas. Lanjutnya, ia mencontohkan bahwa apabila ada seseorang yang dipidana tanpa adanya kesalahan, tentunya akan melukai perasaan keadilan.

Asas Tiada Pidana Tanpa Kesalahan atau Asas Kesalahan mengandung pengertian bahwa seseorang yang telah melakukan perbuatan yang bertentangan dengan peraturan hukum pidana yang berlaku, tidak dapat dipidana oleh karena ketiadaan kesalahan dalam perbuatannya tersebut. Asas ini termanifestasi dalam pasal 6 ayat (2) Undang-undang Nomor 4 Tahun 2004 tentang Kekuasaan Kehakiman, yang menentukan bahwa:

“Tidak seorang pun dapat dijatuhi pidana, kecuali apabila pengadilan karena alat pembuktian yang sah menurut undang-undang, mendapat keyakinan bahwa seseorang yang dianggap dapat bertanggung jawab, telah bersalah atas perbuatan yang didakwakan atas dirinya".

Guna mengetahui mengapa asas "tiada pidana tanpa kesalahan" ini sebagai suatu asa yang penting perlu diketahui apa yang dimaksud dengan asas ini E.Ph. R. Sutorius mencoba mengartikan asas “tiada pidana tanpa kesalahan”. Menurutnya7,

"pertama-tama harus diperhatikan bahwa kesalahan selalu hanya mengenai perbuatan yang tidak patut, yaitu melakukan sesuatu yang seharusnya tidak dilakukan dan tidak melakukan sesuatu yang seharusnya dilakukan."

Apabila dikaitkan dengan beberapa teori pertanggungjawaban pidana korporasi seperti "identification theory" maka tetap disyaratkan kedudukan dan kewenangan dari orang yang bersangkutan dikaitkan dengan tindak pidana yang dilakukan. Doktrin ini berasal dari negeri Anglo Saxon. Muladi berpendapat bahwa doktrin identifikasi sebuah perusahaan dapat melakukan sejumlah delik secara langsung melalui orang-orang yang sangat berhubungan erat dengan perusahaan. 8

Berdasarkan uraian di atas, memang korporasi dapat dijadikan subjek tindak pidana dan bisa dijatuhi pidana (dipertanggungjawabkan). Untuk pertanggungjawaban pidana korporasi telah diterbitkan dan diberlakukan Peraturan Mahkamah Agung Nomor

$7 \quad$ Klitgaard Robert, Penuntun Pemberantasan Korupsi dalam Pemerintahan Daerah, alih bahasa oleh Masri Maris, Jakarta: Yayasan Obor Indonesia, 2005, hlm. 82.

8 Nawawi Barda Arief, Bunga Rampai Kebijakan Hukum Pidana (Perkembangan Penyusunan Konsep KUHP Baru), Jakarta: Kencana Prenada Media Group, 2008, hlm. 76. 
13 Tahun 2016 tentang Tata Cara Penanganan Perkara Tindak Pidana Oleh Korporasi ini dimaksudkan untuk mengisi kekosongan hukum khususnya hukum acara pidana dalam penanganan perkara pidana dengan pelaku Korporasi dan/atau Pengurus dan dapat dijadikan pedoman bagi penegak hukum dalam penanganan perkara pidana dengan pelaku Korporasi dan/atau Pengurus sehingga terwujudlah efektivitas dan optimalisasi penanganan perkara pidana dengan pelaku Korporasi dan/atau Pengurus. ${ }^{9}$ Untuk adanya kesatuan pemahaman tentang pengertian maka Peraturan Mahkamah Agung mendefinisikan tindak pidana Korporasi yaitu tindak pidana yang dilakukan oleh orang berdasarkan hubungan kerja, atau berdasarkan hubungan lain, baik sendiri-sendiri maupun bersama-sama yang bertindak untuk dan atas nama Korporasi di dalam maupun di luar Lingkungan Korporasi. ${ }^{10}$

Oleh karenanya Peraturan Mahkamah Agung menentukan bahwa dalam menjatuhkan pidana terhadap korporasi, hakim dapat menilai kesalahan korporasi antara lain: Pertama, korporasi dapat memperoleh keuntungan atau manfaat dari tindak pidana tersebut atau tindak pidana tersebut dilakukan untuk kepentingan korporasi; Kedua, korporasi membiarkan terjadinya tindak pidana; atau Ketiga, korporasi tidak melakukan langkah-langkah yang diperlukan untuk melakukan pencegahan, mencegah dampak yang lebih besar dan memastikan kepatuhan terhadap ketentuan hukum yang berlaku guna menghindari terjadinya tindak pidana. ${ }^{11}$

\section{KESIMPULAN}

Korporasi merupakan subjek hukum yang dapat dipertanggungjawabkan dalam tindak pidana pencucian uang sebagaimana yang diatur Undang-undang Nomor 8 Tahun 2010. Pemidanaan yang dapat dilakukan terhadap korporasi adalah pidana pokok dan pidana tambahan. Pidana dapat dijatuhkan terhadap Korporasi apabila tindak pidana Pencucian Uang dalam hal dilakukan atau diperintahkan oleh Personil Pengendali Korporasi; dilakukan dalam rangka pemenuhan maksud dan tujuan Korporasi; dilakukan sesuai dengan tugas dan fungsi pelaku atau pemberi perintah; dan dilakukan dengan maksud memberikan manfaat bagi Korporasi. Undang-undang Nomor 8 Tahun 2010 memberikan

9 Pasal 2 Peraturan Mahkamah Agung Nomor 13 Tahun 2016 tentang Tata Cara Penanganan Perkara Tindak Pidana Oleh Korporasi.

10 Pasal 4 ayat (1) Peraturan Mahkamah Agung Nomor 13 Tahun 2016 tentang Tata Cara Penanganan Perkara Tindak Pidana Oleh Korporasi.

11 Pasal 4 ayat (2) Peraturan Mahkamah Agung Nomor 13 Tahun 2016 tentang Tata Cara Penanganan Perkara Tindak Pidana Oleh Korporasi. 
kemungkinan juga adanya penjatuhan pidana kurungan pengganti denda dijatuhkan terhadap Personil Pengendali Korporasi dengan memperhitungkan denda yang telah dibayar. Di dalam masalah pertanggungjawaban pidana korporasi, perlu diperhatikan bahwa di berbagai negara penuntutan dan pemidanaan korporasi dikenal apa yang dinamakan "punishment provisions" artinya baik pelaku (pengurus) maupun korporasi itu sendiri dapat dijadikan subjek pemidanaan, di samping pula perlu dicermati efek pemidanaan terhadap korporasi yang berdampak negatif. Pemidanaan terhadap korporasi harus sesuai dengan pendirian integratif tentang tujuan pemidanaan yaitu dalam fungsinya sebagai sarana pencegahan (umum dan khusus) dan perlindungan masyarakat.

\section{Daftar Pustaka}

\section{Buku}

Adami, Chazawi, Pelajaran Hukum Pidana Bagian Penafsiran Hukum Pidana Dasar Peniadaan Pemberatan \& Peringanan Kejahatan Aduan, Perbarengan \& Ajaran Kausalitas, Jakarta: PT Raja Grafindo Persada, 2002.

Alfitra, Modus Operandi Pidana Khusus di Luar KUHP, Jakarta: Penerbit Raih Asa Sukses, 2014.

Arief, Nawawi Barda, Bunga Rampai Kebijakan Hukum Pidana (Perkembangan Penyusunan Konsep KUHP Baru), Jakarta: Kencana Prenada Media Group, 2008.

Dimyati, Khudzaifah \& Kelik Wardiono (ed), Problema Globalisasi: Perspektif Sosiologi Hukum, ekonomi dan Agama, Surakarta: Muhammadiyah University Press, 2001.

Fisse, Brent, David Fraser \& Graeme Coss, Economics and Ideology on the Money Trail (Confiscation of Proceeds of Crime, Money Laundering and Cash Transaction Reporting), Sydney: The Law Book Company Limited, 1992.

Muladi \& Barda Nawawi Arief, Teori-teori dan Kebijakan Hukum Pidana, Bandung: Alumni, 2005.

Robert, Klitgaard, Penuntun Pemberantasan Korupsi dalam Pemerintahan Daerah, alih bahasa oleh Masri Maris, Jakarta: Yayasan Obor Indonesia, 2005.

Sutan, Remy Syahdeini, Seluk Beluk Tindak Pidana Pencucian Uang dan Pembiayaan Terorisme, Jakarta: Pusat Pustaka Grafiti, 2007. 


\section{Peraturan Perundang-undangan}

Peraturan Mahkamah Agung Nomor 13 Tahun 2016 tentang Tata Cara Penanganan Perkara Tindak Pidana Oleh Korporasi. 